\title{
Nutrient Digestibility and Productivity of Bali Cattle Fed Fermented Hymenachne amplexiacalis Based Rations Supplemented with Leucaena leucocephala
}

\author{
Riswandi*, A. I. M. Ali, Muhakka, Y. Syaifudin, \& I. Akbar \\ Department of Animal Science, Faculty of Agriculture, University of Sriwijaya \\ Research Center for Sub-optimal Lands (PUR-PLSO), University of Sriwijaya \\ Jalan Palembang-Prabumulih KM. 32, Indralaya, Ogan Ilir, South Sumatera, Indonesia 30662 \\ (Received 23-03-2015; Reviewed 10-06-2015; Accepted 09-09-2015)
}

\begin{abstract}
An experiment was conducted to study the effects of lamtoro (Leucaena leucocephala) leaf supplementation in fermented kumpai grass (Hymenachne amplexiacalis) based rations on the productivity of Bali cattle. Variables measured were dry matter and organic matter intakes, nutrient digestibility (dry matter, organic matter, crude protein, and crude fiber), body weight gain, and feed efficiency. The types of rations were: Ration $A=45 \%$ fermented kumpai grass $+40 \%$ benggala grass $+15 \%$ concentrate $+0 \%$ lamtoro leaf, Ration $B=45 \%$ fermented kumpai grass $+30 \%$ benggala grass $+15 \%$ concentrate $+10 \%$ lamtoro leaf, Ration $C=45 \%$ fermented kumpai grass $+20 \%$ benggala grass $+15 \%$ concentrate $+20 \%$ lamtoro leaf, and Ration $\mathrm{D}=\mathbf{4 5} \%$ fermented kumpai grass $+10 \%$ benggala grass $+15 \%$ concentrate $+30 \%$ lamtoro leaf. The supplementation of lamtoro leaf up to $30 \%$ into the ration could increase $(\mathrm{P}<0.05)$ dry matter and organic matter intakes, and crude protein digestibility. The highest body weight gain and feed efficiency were found in Bali cattle fed ration with $20 \%$ lamtoro leaf supplementation. The level of lamtoro leaf supplementation in the ration did not affect the digestibility of dry matter, organic matter, and crude fiber. It was concluded that the supplementation of lamtoro leaf in the ration could increase dry matter, organic matter, and crude protein intakes. Addition of $20 \%$ lamtoro leaf gave the best effect on the increased body weight gain and feed efficiency in Bali cattle.
\end{abstract}

Key words: Hymenachne amplexiacalis, Leucaena leucocephala, productivity, Bali cattle

\section{ABSTRAK}

Tujuan penelitian ini adalah untuk mempelajari pengaruh suplementasi daun lamtoro (Leucaena leucocephala) pada ransum berbahan dasar rumput kumpai (Hymenachne amplexiacalis) fermentasi terhadap produktivitas ternak sapi bali. Peubah yang diamati adalah konsumsi bahan kering, bahan organik, koefisien cerna bahan kering, koefisien cerna bahan organik, koefisien cerna protein kasar, koefisien cerna serat kasar, pertambahan bobot badan, dan efisiensi ransum. Perlakuan yang diberikan adalah sebagai berikut: $A=45 \%$ rumput kumpai fermentasi $+40 \%$ rumput benggala $+15 \%$ konsentrat $+0 \%$ lamtoro, $B=45 \%$ rumput kumpai fermentasi $+30 \%$ rumput benggala $+15 \%$ konsentrat $+10 \%$ lamtoro, $C=45 \%$ rumput kumpai fermentasi $+20 \%$ rumput benggala $+15 \%$ konsentrat $+20 \%$ lamtoro, dan $\mathrm{D}=45 \%$ rumput kumpai fermentasi $+10 \%$ rumput benggala $+15 \%$ konsentrat + 30\% lamtoro. Hasil penelitian menunjukkan bahwa perlakuan penambahan daun lamtoro sampai level $30 \%$ dapat meningkatkan $(\mathrm{P}<0,05)$ konsumsi bahan kering, bahan organik, dan kecernaan protein kasar. Nilai pertambahan bobot badan dan efisiensi ransum yang tertinggi terdapat pada perlakuan dengan penambahan lamtoro $20 \%$. Perlakuan dengan penambahan lamtoro belum mampu meningkatkan nilai kecernaan bahan kering, bahan organik, dan serat kasar. Dapat disimpulkan bahwa penambahan daun lamtoro dapat meningkatkan konsumsi bahan kering, bahan organik, dan protein kasar. Penambahan daun lamtoro pada taraf $20 \%$ memberikan pengaruh terbaik pada peningkatan pertambahan bobot badan dan efisiensi ransum ternak sapi bali.

Kata kunci: Hymenachne amplexiacalis, Leucaena leucocephala, produktivitas, sapi Bali

*Corresponding author:

E-mail: riswandi_dya@yahoo.com 


\section{INTRODUCTION}

Feed is the main factor in the animal husbandry business since $60 \%-70 \%$ of total operational cost is feed cost. A good quality feed is a feed that meets the nutrient requirement of the animal for maintenance, growth, and productivity. The increased population of animal should be balanced by the increase in the supply of good feed in quality, quantity, and continuity (Haryanto, 2012). Feeds consumed by ruminant animals are mostly grasses and forages that must be available and meet the requirement of animals both in quantity and quality (Fernandes, 2007). Nutritionally, forage is a source of fiber, and the supply and the production of forage and grass are determined by the season and climate. The availability of land for grass and forage production for supplying feed for animal industry is decrease due to the increased use of land for plant agriculture, plantation, industrial, and residential development.

Wet-land forages have a great potential for feed diversity to sustain the availability and supply of quality feed that does not compete with human need. The use of wet-land forage as a potential source of nonconventional feed resources is needed to be considered (Syarifuddin \& Wahdi, 2010; Akhadiarto \& Fariani, 2012). This alternative feed could be used as a main ruminant feed in the future and its use should be increased by optimizing the use of wet-land forage and tree legume as a quality feed for animal industry.

Kumpai grass (Hymenachne amplexiacalis (Rudge) Nees) is one of forages that mostly found in the wet land. The productivity of this wet-land forage is high but its nutritive value is low. Rostini et al. (2014) reported that kumpai grass had crude protein content around $10.88 \%$ with crude fiber content around $16.37 \%$, NDF around $62.60 \%$, and ADF around $36.75 \%$. Fariani and Evitayani (2008) reported that the content of fiber fraction of wet-land grass was 71\% NDF, 47.07\% ADF, $36.32 \%$ cellulose, and $29.93 \%$ hemicellulose, so that the nutritive value of wet-land grass needed to be improved by supplementing the grass with tree legume such as lamtoro (Luecaena leucocephala) leaf as a source of bypass protein.

By-pass protein is a protein in the feed of ruminant animals that is not degraded by the rumen microbes. The result is the protein will be digested enzymatically in the abomasum and intestine to produce amino acids. The increased supply of by-pass protein in the feed that is not degraded in the rumen is designed to increase the amount of protein and amino acids that enter the intestine that will be digested and reabsorbed in the intestine (Widyobroto et al., 2007). By-pass protein is important for ruminant animals since this protein could increase the availability of protein in post-rumen digestion and absorption. In ruminant animals that are in production stage the use of by-pass protein could increase the efficiency of protein use so that increase the number of protein that by pass the rumen into the abomasum and intestine (Sun et al., 2009) that would be digested into amino acids.

Lamtoro is a tree legume that belongs to multipurpose plant with crude protein content of $20.40 \%, 2.30 \%$
Ca, and $0.23 \% \mathrm{P}$ with carotene content of $530.00 \mathrm{mg} /$ $\mathrm{kg}$ and tannin content of $10.15 \mathrm{mg} / \mathrm{kg}$. Lamtoro could be used as a source of by-pass protein in feed formulation since this legume contains tannin that protects the feed protein from degradation and digestion by rumen microbes (Kavana et al., 2005) that finally increase nutritive value of a ration. This experiment was designed to analyze the optimum level of lamtoro leaf supplementation in fermented kumpai grass based ration on feed consumption, nutrient digestibility, and body weight gain in Bali cattle.

\section{MATERIALS AND METHODS}

\section{Materials}

The concentrated used in the formulation of diet was rice bran, corn meals, bekatul, ultra mineral, urea, and salt (Table 1). The ration was formulated with a final $11 \%-14 \%$ crude protein content and 54\%-60\% TDN (Table 2).

The experiment used 4 male Bali cattle with 1 year of age and body weight ranged of $110-140 \mathrm{~kg}$. The experimental cattle were maintained in metabolic cages provided with feed and water. The feces and urine were collected separately so that the urine was not mixed with feces.

Kumpai grass fermentation was conducted to improve and increase the nutritive values of the kumpai grass. Fermentation was conducted by adding $8 \%$ probiotic (inoculant) and 5\% molasses per weight of kumpai grass. Before fermentation and mixing with prebiotic and molasses, the kumpai grass was cut to the size of $3 \mathrm{~cm}$ and then shriveled or dried to decrease the moisture content. Probiotic used was EM-4 (Effective microorganism-4) type (PT. Songgolangit Persada Bali) containing Lactobacillus casei, Saccharomyces cerevisiae, and Rhodopseudomonas palustris. Silage materials were put into a plastic bag (silo), compacted, and then the plastic bag was tied tightly so the condition inside the bag was anaerobe. The plastics bags containing silage were maintained in a room with temperature ranged of $26-28^{\circ} \mathrm{C}$ for $21 \mathrm{~d}$ (Riswandi, 2014). Silage produced dur-

Table 1. Crude protein $(\mathrm{CP})$, crude fiber $(\mathrm{CF})$, and total digestible nutrient (TDN) of feeds used for formulation of the experimental rations (\%)

\begin{tabular}{lrrr}
\hline \multicolumn{1}{c}{ Ingredients } & \multicolumn{1}{c}{ CP } & \multicolumn{1}{c}{ CF } & TDN \\
\hline Rice brans & 11.20 & 18.51 & 65.00 \\
Corn meal & 10.50 & 2.00 & 83.00 \\
Bekatul & 14.00 & 7.50 & 87.60 \\
Mineral & 0.00 & 0.00 & 0.00 \\
Salt & 0.00 & 0.00 & 0.00 \\
Urea & 261.00 & 0.00 & 0.00 \\
Fermented kumpai grass & 11.62 & 30.16 & 59.30 \\
Benggala grass & 10.50 & 35.64 & 45.30 \\
Lamtoro leaf & 23.20 & 23.58 & 63.10 \\
\hline
\end{tabular}

Note: Data were analyzed by Laboratory of Nutrition and Feed Science, Faculty of Agriculture, University of Sriwijaya (2014). 
Table 2. Composition of experimental rations (\%)

\begin{tabular}{lcccc}
\hline \multirow{2}{*}{\multicolumn{1}{c}{ Ingredient }} & \multicolumn{4}{c}{ Type of rations } \\
\cline { 2 - 5 } & $\mathrm{A}$ & $\mathrm{B}$ & $\mathrm{C}$ & $\mathrm{D}$ \\
\hline Fermented kumpai grass & 45 & 45 & 45 & 45 \\
Benggala grass & 40 & 30 & 20 & 10 \\
Concentrate & 15 & 15 & 15 & 15 \\
Lamtoro leave & 0 & 10 & 20 & 30 \\
(supplement) & & & & \\
Nutrient composition & & & & \\
$\quad$ Crude protein & 11.40 & 12.48 & 13.37 & 14.13 \\
$\quad$ Crude fiber & 30.19 & 29.59 & 29.09 & 28.66 \\
$\quad$ Total digestible nutrient & 54.92 & 55.66 & 56.28 & 56.80 \\
\hline
\end{tabular}

Note: Ration $\mathrm{A}=(45 \%$ fermented kumpai grass $+40 \%$ benggala grass $)+$ $15 \%$ concentrate $+0 \%$ lamtoro leave, $\mathrm{B}=(45 \%$ fermented kumpai grass $+30 \%$ benggala grass $)+15 \%$ concentrate $+10 \%$ lamtoro leave, $\mathrm{C}=(45 \%$ fermented kumpai grass $+20 \%$ benggala grass $)+$ $15 \%$ concentrate $+20 \%$ lamtoro leave, $\mathrm{D}=(45 \%$ fermented kumpai grass $+10 \%$ benggala grass) $+15 \%$ concentrate $+30 \%$ lamtoro leave.

ing $21 \mathrm{~d}$ incubation was fed to the experimental cattle during the experiment.

\section{Preparation of Pen and Experimental Cattle}

Before the experimental Bali cattle were maintained in the pen, the pens were cleaned, limed, and disinfected with disinfectant. Before the experiment, the experimental cattle were administered anthelmintic. The pens were numbered and the experimental cattle were assigned into each pen randomly with the experimental ration.

\section{Feeding and Drinking Water}

The feed was given based on dry matter requirement i.e., 3\% of body weight. Concentrate was given separately from grass. Concentrate was given at 8.00 WIB in the morning and then followed by administration of forage feed at 11.00 WIB and 15.00 WIB. Drinking water was available ad libitum. The drinking water was replaced and added daily.

\section{Data Collection}

The experiment was conducted in the experimental pens and Laboratory of Animal Nutrition and Feed, Faculty of Agriculture, University of Sriwijaya. The experiment was conducted in several periods i.e., adaptation, preliminary, growth, and collection. Adaptation period was conducted for $1 \mathrm{moh}$ to adapt the experimental cattle to the experimental condition, ration, and animal maintenance. Preliminary period was conducted to remove the residues of previous feed consumed by the experimental cattle. This period was conducted for $15 \mathrm{~d}$.

Growth period was the period for measuring body weight gain of the experimental cattle. This period was designed to study the effect of experimental ration on the body weight gain of the experimental cattle. The growth period was conducted for $30 \mathrm{~d}$. The experimental cattle were weighed $3 \mathrm{~d}$ consecutively in the beginning of the period and $3 \mathrm{~d}$ consecutively at the end of the period. Collection period was designed to record and measure the digestibility of nutrients. This period was conducted for $1 \mathrm{wk}$. During this period, the feces were collected daily for $24 \mathrm{~h}$ and the samples of feed were collected daily. The weight of the feces was recorded and $10 \%$ of the total weight of the feces was collected for sample analysis.

\section{Procedures of Variables Measurement}

Dry matter consumption. Dry matter consumption was calculated by multiplying the fresh feed fed with dry matter content of the ration and the result was subtracted with dry matter of the unconsumed feed that was calculated in kilogram per day (Imran et al., 2012).

Dry matter digestibility. Dry matter digestibility was calculated by subtracting dry matter consumed with dry matter of the feces and the result was divided by the total dry matter consumed and multiplied by $100 \%$ (Pond et al., 2005). Dry matter consumption was based on the results of proximate analysis and the dry matter of the feces was calculated by averaging the dry matter of feces measured during the last week of experimental period. The digestibility coefficient of dry matter (DCDM) was calculated by the following formula:

$\mathrm{DCDM} \%=[($ dry matter consumption - dry matter of feces)/dry matter consumption] x $100 \%$

Organic matter digestibility. Organic matter digestibility was obtained by subtracting the consumption of organic matter with organic matter of the feces and the result was divided by organic matter consumption and multiplied by $100 \%$ (Pond et al., 2005). Organic matter consumption was based on the proximate analysis and the dry matter of feces was calculated by averaging the organic matter of the feces measured during the last week of the experimental period. The digestibility coefficient of organic matter (DCOM) was calculated by using the following formula:

DCOM $\%=[$ (consumption of organic matter - organic matter of the feces)/consumption of organic matter] x $100 \%$

Protein digestibility. Protein digestibility was obtained by subtracting the protein consumed with the protein of the feces and the result was divided with protein consumption and the result was multiplied by $100 \%$ (Pond et al., 2005). Protein consumption was based on the results of proximate analysis and protein content of the feces was calculated by averaging the protein contents of the feces measured during the last week of experimental period. Digestibility coefficient of crude protein (DCCP) was calculated by the following formula:

DCCP $\%=[$ (consumption of crude protein - feces crude protein)/consumption of crude protein] $x$ $100 \%$ 
Crude fiber digestibility. Fiber digestibility was calculated by subtracting the consumption of crude fiber with crude fiber content of the feces and the result was divided by the consumption of the crude fiber and then the result was multiplied by $100 \%$ (Pond et al., 2005). The consumed crude fiber was based on the result of proximate analysis of the ration and feces crude fiber was calculated by averaging crude fiber of the feces measured during the last week of the experimental period. Digestibility coefficient of crude fiber (DCCF) was calculated by using the following formula:

DCCF $\%=[$ (consumption of crude fiber - crude fiber of the feces)/consumption of crude fiber] $\times 100 \%$

Body weight gain. Body weight gain is a difference between the final body weight at the end of experiment and the body weight at the beginning of experiment (Imran et al., 2012).

Feed efficiency. Feed efficiency was calculated by dividing the body weight gain with the total feed consumption during the experimental period and the result was multiplied by $100 \%$ (Campbell et al., 2006).

\section{Data Analysis}

The experiment used Latin Square Design with a 4 x 4 arrangement with row as 4 periods of experiment, column as 4 Bali cattle, and 4 types of ration used as a treatment. The treatments used were: Ration $\mathrm{A}=45 \%$ fermented wet grass $+40 \%$ benggala grass $+15 \%$ concentrate $+0 \%$ lamtoro leaf; Ration $B=45 \%$ fermented wet grass $+30 \%$ benggala grass $+15 \%$ concentrate + $10 \%$ lamtoro leaf; Ration C $=45 \%$ fermented wet grass $+20 \%$ benggala grass $+15 \%$ concentrate $+20 \%$ lamtoro leaf; Ration $\mathrm{D}=45 \%$ fermented wet grass $+10 \%$ benggala grass $+15 \%$ concentrate $+30 \%$ lamtoro leaf (Table 2 ).

The collected data were analyzed for variance by using ANOVA and if there was a difference between treatment the difference was tested by Duncan (Steel \& Torrie, 1991).

\section{RESULTS AND DISCUSSION}

\section{Dry Matter and Organic Matter Consumption}

The results of analysis of variance showed that supplementation of various levels of lamtoro leaf in ration based on fermented kumpai grass significantly increased $(\mathrm{P}<0.05)$ dry matter and organic matter consumptions. The range of dry matter consumption in this experiment was $6.72-8.18 \mathrm{~kg}$ and the range of organic matter consumption was $6.12-7.47 \mathrm{~kg}$. The significant differences in dry matter and organic matter consumptions among treatments were caused by the nutrient content, especially protein and energy contents of the experimental rations and the materials used in the rations (Lewis \& Emmans, 2010; Aregheore, 2006). Lamtoro leaf supplementation plays a significant role in increasing protein content of the experimental rations that affect dry matter consumption. Supplementation of lamtoro leaf could increase the palatability of the ration. Further test showed that the highest dry matter and organic matter consumptions were found in ration D i.e., ration contained $30 \%$ lamtoro and the lowest level was found in ration A i.e., ration without lamtoro leaf supplementation (Table 3). This result was caused by the higher crude protein content in the $\operatorname{diet} \mathrm{D}$ as compared to those in diets $A, B$, and $C$. The higher the levels of lamtoro leaf supplementation the higher the crude protein content of the ration because lamtoro is a legume with a rich content of crude protein. This result indicated that the higher the crude protein contents of the ration the higher the palatability of the ration. The same result was also reported by Sanh et al. (2002) that found that the higher the level of crude protein of the diet the higher the palatability and digestibility of the ration. Further Parakkasi (1999) stated that the amount of dry matter consumed was affected by several factors i.e., (a) physical or chemical characteristics of the diet, (b) the physiological requirement of the experimental animal for maintenance and production according to the capacity of digestive tract, (c) live body weight that related with the development of the digestive tract, since the capacity of the digestive tract was generally increased with the increase in the live body weight so that the digestive tract could accommodate the higher amount of dry matter.

\section{Nutrient Digestibility}

The analysis of variance showed that the level of lamtoro leaf supplementation in the ration did not affect the digestibility of dry matter, organic matter, and crude fiber, but significantly increased $(\mathrm{P}<0.05)$ crude protein digestibility (Table 4 ). This result could be related to the increase in crude protein content of the ration with the lamtoro leaf supplementation since the lamtoro leaf is rich in crude protein. The dry matter digestibility of the experimental diets ranged from $78.66 \%$ to $79.75 \%$ and the digestibility of organic matter ranged from $80.78 \%$ to $81.49 \%$. The results found in the present experiment is in accordance with the result reported by Wanapat et al. (2011) that the supplementation of lamtoro leaf at the level of $23.7 \%$ does not affect the digestibility of dry

Table 3. Dry matter and organic matter intakes of Bali cattle fed with different levels of lamtoro leaf supplementation in the fermented kumpai grass based ration

\begin{tabular}{lcccc}
\hline \multirow{2}{*}{ Intake } & \multicolumn{4}{c}{ Type of ration } \\
\cline { 2 - 5 } & $\mathrm{A}$ & $\mathrm{B}$ & $\mathrm{C}$ & $\mathrm{D}$ \\
\hline $\begin{array}{l}\text { Dry matter } \\
\text { intake }(\mathrm{kg})\end{array}$ & $6.72 \pm 0.13^{\mathrm{a}}$ & $7.34 \pm 0.15^{\mathrm{b}}$ & $8.05 \pm 0.22^{\mathrm{c}}$ & $8.18 \pm 0.20^{\mathrm{d}}$ \\
$\begin{array}{l}\text { Organic matter } \\
\text { intake }(\mathrm{kg})\end{array}$ & $6.12 \pm 0.11^{\mathrm{a}}$ & $6.68 \pm 0.14^{\mathrm{b}}$ & $6.67 \pm 0.20^{\mathrm{c}}$ & $7.47 \pm 0.18^{\mathrm{d}}$ \\
\hline
\end{tabular}

Note: Means in the same row with different superscripts differ significantly $(\mathrm{P}<0.05)$. Ration $\mathrm{A}=(45 \%$ fermented kumpai grass $+40 \%$ benggala grass $)+15 \%$ concentrate $+0 \%$ lamtoro leave, $\mathrm{B}=(45 \%$ fermented kumpai grass $+30 \%$ benggala grass $)+15 \%$ concentrate $+10 \%$ lamtoro leave, $C=(45 \%$ fermented kumpai grass $+20 \%$ benggala grass $)+15 \%$ concentrate $+20 \%$ lamtoro leave, $D=(45 \%$ fermented kumpai grass $+10 \%$ benggala grass) $+15 \%$ concentrate $+30 \%$ lamtoro leave. 
Table 4. Digestibility of dry matter, organic matter, crude protein, and crude fiber of different types of rations with different levels of lamtoro leaf supplementation in the fermented kumpai grass based ration in Bali cattle

\begin{tabular}{lcccc}
\hline \multirow{2}{*}{ Digestibilities } & \multicolumn{4}{c}{ Type of rations } \\
\cline { 2 - 5 } & $\mathrm{A}$ & $\mathrm{B}$ & $\mathrm{C}$ & $\mathrm{D}$ \\
\hline Dry matter digestibility (\%) & $79.75 \pm 2.93$ & $78.66 \pm 4.96$ & $79.45 \pm 4.14$ & $79.15 \pm 5.36$ \\
Organic matter digestibility (\%) & $81.49 \pm 1.74$ & $80.78 \pm 2.24$ & $81.02 \pm 3.62$ & $80.98 \pm 4.76$ \\
Crude protein digestibility (\%) & $68.61 \pm 4.04^{\mathrm{a}}$ & $68.36 \pm 5.78^{\mathrm{a}}$ & $67.78 \pm 5.40^{\mathrm{a}}$ & $76.73 \pm 4.48^{\mathrm{b}}$ \\
Crude fiber digestibility (\%) & $83.33 \pm 2.25$ & $82.07 \pm 4.74$ & $82.56 \pm 3.43$ & $85.29 \pm 3.27$ \\
\hline
\end{tabular}

Note: Means in the same row with different superscripts differ significantly $(\mathrm{P}<0.05)$. Ration $\mathrm{A}=(45 \%$ fermented kumpai grass $+40 \%$ benggala grass $)$ $+15 \%$ concentrate $+0 \%$ lamtoro leave, $\mathrm{B}=(45 \%$ fermented kumpai grass $+30 \%$ benggala grass $)+15 \%$ concentrate $+10 \%$ lamtoro leave, $\mathrm{C}=(45 \%$ fermented kumpai grass $+20 \%$ benggala grass $)+15 \%$ concentrate $+20 \%$ lamtoro leave, $\mathrm{D}=(45 \%$ fermented kumpai grass $+10 \%$ benggala grass $)$ $+15 \%$ concentrate $+30 \%$ lamtoro leave.

matter and organic matter in lactating dairy cows fed with ration based on ammoniated straw. The digestibility of dry matter and organic matter in each type of ration did not show a significant difference. Even though the dry matter and organic matter consumptions showed a significant difference, there was no significant difference in the digestibility of dry matter and organic matter. The digestibility of organic matter decreased due to the increased feed consumption since the retention time of the feed in the digestive tract became shorter that eventually decreased the fermentation of feed by rumen microbes (Church, 1988).

The values of dry matter and organic matter digestibilities in the ration without lamtoro leaf supplementation tended to be higher as compared to rations with lamtoro leaf supplementation. This result indicated that the increased level of lamtoro leaf supplementation would increase the amount of tannin in the ration that protect the nutrient such as crude protein and carbohydrate so that the tannin content of the diet would affect the digestibility of dry matter and organic matter of the diet that was tended to decrease with the addition of lamtoro leaf. As it is known that tannin is a polyphenol compound that has capacity to bind protein and other compounds (such as carbohydrate, mineral, and vitamin) and form a complex compound. In general, tannin has the ability to decrease the use of feed (Suhartati, 2005; Yulistiani et al., 2011). The values of crude fiber digestibility in this experiment ranged from 82.07 to $85.29 \%$. The value of crude fiber digestibility in diet D tended to be higher as compared to diets A, B and C. This result was caused by the higher level of lamtoro leaf supplementation that could decrease the crude fiber content of the ration that eventually increased the values of crude fiber digestibility of ration with $30 \%$ level of lamtoro leaf supplementation (ration D).

The range of crude protein digestibility in this experiment was $67.78 \%-76.73 \%$. Further test showed that the highest level of crude protein was found in ration supplemented with $30 \%$ lamtoro leaf (ration D) that was significantly different $(\mathrm{P}<0.05)$ from rations $\mathrm{A}, \mathrm{B}$, and $C$. There was no significant difference among diets A, B, and C. This result was caused by the higher tannin content of ration D (ration with $30 \%$ level of lamtoro leaf supplementation) as compared to rations A, B, and C. There was no significant difference in crude fiber digestibility among ration A (0\% lamtoro leaf), B (10\% lamtoro leaf), and C (20\% lamtoro leaf). This result was caused by the level of tannin in rations $A, B$, and $C$ that were not optimum to protect protein from degradation by rumen microbe so that the crude protein digestibility among treatments were similar. It was known that tannin found in the lamtoro leaf would bind with protein, and protein would be protected from degradation by rumen microbes so that the number protein entered post-rumen digestive tract would increase so that the digestibility of crude protein in the intestine would increase. This result indicated that the higher the crude protein contents of the ration the higher the digestibility of nutrients. This result is in accordance with the results reported by Suhartati (2005) and Widyobroto et al. (2007) that the increased concentration of by-pass protein is caused by the binding between tannin and protein to form complex compounds that insoluble in the rumen that could be directly digested enzymatically in the post rumen. The effect of tannin on organic matter of the ration is more significant on protein component as compared to the other components of the rations (Getachew et al., 2008).

\section{Body Weight Gain}

Further test showed that Bali cattle fed with ration C (supplemented with 20\% lamtoro leaf) gave a significantly higher $(\mathrm{P}<0.05)$ body weight gain as compared to those fed with rations $A, B$, and D. There was also a significant difference in body weight gain among the Bali cattle fed with rations A, B, and D. The highest body weight gain was found in Bali cattle fed with ration $C(0.61 \mathrm{~kg})$ and the lowest level was found in those fed with ration $B(0.32 \mathrm{~kg})$ (Table 5$)$. This result is probably related to the differences in nutrient contents, consumption or intake and digestibility of dry matter and nutrient with the lamtoro leaf supplementation in the diet. This result is in agreement with the statement of Simanihuruk et al. (2006) that daily body live weight gain is a reflection of accumulation of consumption, fermentation, metabolism, and absorption of nutrients in the body (digestive tracts) and is a reflection of feed quality and feed biological value.

The ranges of daily body weight gain were 0.32 to $0.61 \mathrm{~kg}$. The highest average daily body weight gain in 
Table 5. Average daily live weight gain and feed efficiency of Bali cattle fed with different levels of lamtoro leaf supplementation in the fermented kumpai grass based ration

\begin{tabular}{lcccc}
\hline \multirow{2}{*}{ Variables } & \multicolumn{4}{c}{ Types of rations } \\
\cline { 2 - 5 } & $\mathrm{A}$ & $\mathrm{B}$ & $\mathrm{C}$ & $\mathrm{D}$ \\
\hline $\begin{array}{l}\text { Daily body } \\
\text { weight gain } \\
\text { (kg) }\end{array}$ & $0.38 \pm 0.13^{\mathrm{c}}$ & $0.32 \pm 0.04^{\mathrm{a}}$ & $0.61 \pm 0.13^{\mathrm{d}}$ & $0.36 \pm 0.10^{\mathrm{b}}$ \\
$\begin{array}{l}\text { Feed efficiency } \\
(\%)\end{array}$ & $4.90 \pm 1.61^{\mathrm{c}}$ & $3.79 \pm 0.48^{\mathrm{b}}$ & $6.59 \pm 1.27^{\mathrm{d}}$ & $3.66 \pm 0.97^{\mathrm{a}}$ \\
\hline
\end{tabular}

Note: Means in the same row with different superscripts differ significantly $(\mathrm{P}<0.05)$. Ration $\mathrm{A}=(45 \%$ fermented kumpai grass $+40 \%$ benggala grass) $+15 \%$ concentrate $+0 \%$ lamtoro leave, $\mathrm{B}=(45 \%$ fermented kumpai grass $+30 \%$ benggala grass) $+15 \%$ concentrate $+10 \%$ lamtoro leave, $C=(45 \%$ fermented kumpai grass $+20 \%$ benggala grass $)+15 \%$ concentrate $+20 \%$ lamtoro leave, $D=(45 \%$ fermented kumpai grass $+10 \%$ benggala grass) $+15 \%$ concentrate $+30 \%$ lamtoro leave.

cattle fed with diet $\mathrm{C}$ was due to the optimal level of lamtoro leaf supplementation where the structural and nonstructural carbohydrate contents and protein content met the requirement of the growth of rumen microbes so that the nutrient requirement of the experiment cattle was met with the final result the increased daily body weight gain. The low daily body weight gain in cattle fed with diet B is probably caused by the possibility that part of the protected protein or by-pass protein was not digested completely enzymatically in the post rumen digestive tracts (Sun et al., 2009). In addition, the low daily body weight gain in cattle fed with diet supplemented with $30 \%$ lamtoro leaf is also caused by high content of structural nutrients such as structural carbohydrate (crude fiber) so that when it bound to tannin in post rumen of digestive tract would decrease digestibility and absorption of nutrients in general. Therefore, tannin concentration must be formulated optimally. When the concentration of the tannin is not formulated optimally, the digestibility and absorption of nutrients in general will be disturbed since tannin was not only interact with protein, but also with crude fiber and other components such as vitamin and mineral (Jayanegara et al., 2009; Makkar et al., 2007).

Cattle fed diet without lamtoro leaf supplementation (ration A) had higher daily body weight gain as compared to those fed with rations with lamtoro leaf supplementation (rations B and D). This result is caused by the lower content of anti-nutrient compound in ration without lamtoro leaf supplementation (ration A) so that the biological value (digestibility) of the ration met the optimal requirement for animal growth.

Analysis of variance showed that the lamtoro leaf supplementation up to $20 \%$ could increase $(\mathrm{P}<0.05)$ efficiency values of the ration of Bali cattle. The efficiency values of the experimental rations ranged from $3.66 \%$ to $6.59 \%$.

The effect of treatment on daily body weight gain is a reflection of efficiency of feed or nutrients utilization. The higher the daily body weight gains the higher the efficiency of feed utilization in the body for growth. The efficiency of feed utilization is the ratio between daily live body weight gains with the amount of feed consumed. Especially in ruminant animals, the efficiency of feed utilization is affected by the high quality and biological values of the feed, the values of daily live weight gain and the digestibility of the feed. The significant difference in efficiency of feed utilization as was shown in Table 5 is caused by the relative difference in daily body weight gain, digestibility, feed consumption and biological values of the feed. Further test showed that ration $C$ gave the significantly different effect $(P<0.05)$ as compared to rations $\mathrm{A}, \mathrm{B}$, and $\mathrm{D}$, and among rations $\mathrm{A}$, $\mathrm{B}$, and $\mathrm{D}$ were also showed a significant difference. The highest efficiency of feed utilization was found in cattle fed with ration $C$ i.e., 6.59 and the lowest was found in cattle fed with ration D i.e., $3.66 \mathrm{~kg}$ (Table 5). The highest feed efficiency in cattle fed with diet $C$ showed the optimal level of lamtoro leaf supplementation, where the structural and non-structural carbohydrate content as well as protein content has met the requirement of rumen microbe for growth so that the nutrient requirement of the experimental cattle is also met so the final result is the increased daily body weight gain.

In the treatment of lamtoro leaf supplementation at the level of $20 \%$, the experimental cattle had higher efficiency in utilization of the experimental diet that was reflected in higher body growth rate. The efficiency of feed utilization is affected by several factors such as the capacity or ability of the experimental animals to digest the feed materials, the availability of nutrient for basic or maintenance, the growth and the function of the body, and the type of feed used (Campbell et al., 2006). Feed with higher quality (high crude protein and low crude fiber) has a higher efficiency of feed utilization for energy formation and production (Pond et al., 2005).

\section{CONCLUSION}

The supplementation of lamtoro leaf in the diet based on fermented kumpai grass could increase feed consumption, protein digestion, body weight gain, and feed efficiency. However, lamtoro leaf supplementation could not improve the digestibility of dry matter, organic matter, and crude fiber. The lamtoro leaf supplementation at the level of $20 \%$ gave the best result on daily body weight gain and feed efficiency in Bali cattle.

\section{REFERENCES}

Aregheore, E. M. 2006. Utilization of concentrate supplements containing varying levels of copra cake (Cocos nucifera) by growing goats fed a basal diet of napier grass (Pennisetum purpureum). Small Rumin. Res. 64:87-93. http://dx.doi. org/10.1016/j.smallrumres.2005.04.003

Akhadiarto, S. \& A. Fariani. 2012. Evaluasi kecernaan rumput kumpai minyak (Hymenachne amplexicaulis) amoniasi secara in vitro. Jurnal Sains dan Teknologi Indonesia 14 : 50-55.

Church, D. C. 1988. The Ruminant Animal: Digestive Physiology and Nutrition. Prentice Hall. Engelwood Cliffs. New Jersey.

Campbell, J. R., M. D. Kenealy, \& K. L. Campbell. 2006. Animal Sciences. 4th Edition. McGraw- Hill, New York. 
Fernandes, M. H. M. R. 2007. Energy and protein requirements for maintenance and growth of Boer crossbred kids. J. Anim. Sci. 85:1014-1023. http://dx.doi.org/10.2527/jas.2006110

Fariani \& Evitayani. 2008. The potency of swamp grass as ruminant feed: grass production, carrying capacity and fiber fraction. J. Indon. Trop. Anim. Agric. 33: 299-304.

Getachew, G., W. Pittroff, D. H. Putnam, A. Dandekar, S. Goyal, \& E. J. De Peters. 2008. The influence of addition of gallic acid, tannic acid, or quebracho tannins to alfalfa hay on in vitro rumen fermentation and microbial protein synthesis. Anim. Feed Sci. Technol. 140: 444-461. http://dx.doi. org/10.1016/j.anifeedsci.2007.03.011

Haryanto. B. 2012. Perkembangan penelitian nutrisi ternak ruminansia. Wartazoa 22: 169-177.

Imran, S. P. S. Budhi, N. Ngadiyono, \& Dahlanuddin. 2012. Pertumbuhan pedet sapi bali lepas sapih yang diberi rumput lapangan dan disuplementasi daun turi (Sesbania grandiflora). Jurnal Agrinimal 2: 55-60.

Jayanegara, A., H. P. S. Makkar, \& K. Becker. 2009. In vitro methane emission and rumen fermentation of hay diet contained purified tannins at low concentration. Med. Pet. 32:185-195.

Kavana, V. P. Y., J. B. Kizima, Y. N. Msanga, N. B. Kilongozi, B. S. J. Msangi, L. A. Kadeng'uk, S. Mngulu, \& P. K. Simba. 2005. Potential of pasture and forage for ruminant production in Eastern zone of Tanzania. Livestock Research for Rural Development 17(12).

Lewis, R. M. \& G. C. Emmans. 2010. Feed intake of sheep as aff ected by body weight, breed, sex, and feed composition. J. Anim. Sci. 88:467-480. http://dx.doi.org/10.2527/jas.20081735

Makkar, H. P. S., G. Francis, \& K. Becker. 2007. Bioactivity of phytochemicals in some esserknown plants and their effects and potential applications in livestock and aquaculture production systems. Animal 1: 1371-1391. http:// dx.doi.org/10.1017/S1751731107000298

Parakkasi, A. 1999. Ilmu Nutrisi dan Makanan Ternak Ruminansia. Penerbit Universitas Indonesia, Jakarta.

Pond, W. G., D. C. Church, K. R. Pond, \& P. A. Schoknet. 2005. Basic Animal Nutrition and Feeding. 5th revised edition. John Willey and Sons Inc, New York.
Riswandi. 2014. Evaluasi kecernaan silase rumput kumpai (Hymenachne acutigluma) dengan penambahan legum Turi Mini (Sesbania rostra). Jurnal Peternakan Sriwijaya 3: 43-52.

Rostini, T., L. Abdullah, K. G. Wiryawan, \& P. D. M. H. Karti. 2014. Utilization of swamp forages from South Kalimantan on local goat performances. Med. Pet. 37:50-56. http:// dx.doi.org/10.5398/medpet.2014.37.1.50

Sanh, M. V., H. Wiktorson, \& L. V. Ly. 2002. Effects of natural grass forage to concentrate ratio and feeding principles on milk production and performance of cross bred lactating cows. J. Anim. Sci. 15: 650-657.

Simanihuruk, K., K. G. Wiryawan, \& S. P. Ginting. 2006. The effect of passion fruit hulls level (Passiflora edulis Sims $\mathrm{f}$. edulis Deg) as Kacang goat feed component: I. Intake digestibility and nitrogen retention. JITV 11: 97- 105.

Steel, R. G. D. \& J. H. Torrie. 1993. Prinsip dan Prosedur Statistika. Gramedia Pustaka Utama, Jakarta.

Suhartati, F. M. 2005. Proteksi protein dauin lamtoro (Leucaena leucocephala) menggunakan tanin, saponin, minyak dan pengaruhnya terhadap ruminal undegraded dietary protein (RUDP) dan sintesis protein mikroba rumen. Jurnal Animal Production 7: 52-58.

Sun, T., X. Yu, S. L. Li, Y. X. Dong, \& H. T. Zhang. 2009. Responses of dairy cows to supplemental highly digestible rumen undegradable protein and rumenprotected forms of methionine. Asian-Aust. J. Anim. Sci. 22: 659-666.

Syarifuddin. N. A. \& A. Wahdi. 2010. Kandungan mineral (Na, $\mathrm{Se}, \mathrm{Co}, \mathrm{Fe})$ pakan alami ternak kerbau rawa di Kalimantan Selatan. Media Sains 2 (1).

Wanapat, M., K. Boonnop, C. Promkot, \& A. Cherdthong. 2011. Effects of alternative protein sources on rumen microbes and productivity of dairy cows. Maejo Int. J. Sci. Technol. 5: 13-23.

Widyobroto, B. P., S. P. S. Budhi, \& A. Agus. 2007. Pengaruh aras undegraded protein dan energy terhadap kinetik fermentasi rumen dan sintesis protein mikroba pada sapi. Journal Indonesian Tropic Animal Agriculture 32: 194-200.

Yulistiani, D., I. W. Mathius, \& W. Puastuti. 2011. Bungkil kedelai terproteksi tanin cairan batang pisang dalam pakan domba sedang tumbuh. JITV. 16: 33-40. 